\title{
The Ambiguous Portrayal of Nature in Annibilation
}

\section{Caroline Kjærulff $ه$}

\section{Introduction}

Alex Garland's Annibilation (2018) is not your standard Hollywood film. Annibilation stands out as it is not a straightforward story about environmental apocalypse delivered with a nicely normative message about climate change. Instead, Annibilation leaves its audience with a sense of confusion and disturbance, but perhaps also inspired to rethink their relationship with the environment in a time where sustainable action is crucial. As Sara L. Cosby writes in the introduction of a roundtable review of Annibilation for Gothic Nature: "the film brings to a popular audience a cinematic version of the mindaltering "ecological awareness"' (257). Another element that separates Annibilation from a standard dystopian environmentally conscious film is the fact that the destruction is taking place within an enclosed (albeit expanding) dome. Shannon Davies Mancus writes in "Prison/Prism: Refraction as Radical Praxis in Annihilation":

Because the effects of climate change, though uneven, cannot be contained, most dystopian cli-fi can only offer visions of an environmental future that are devastating on a global level. By constructing The Shimmer as a kind of cataclysmic snow globe, the film is able to both show us a catastrophic environmental future while still presenting hope that the world as we know it can be saved. (269).

As the world outside the Shimmer is still the same, we get the sense that it is not too late to make changes, and this foundation makes it possible for the film to invite the audience to reflect on the message in a, hopefully, productive way. The film is an adaptation of the first book in Jeff VanderMeer's Southern Reach trilogy (2014), or rather, an adaption from Alex Garland's memory of it (Thompson). It is so different that the studio behind got cold feet, as test screening suggested that

Leviathan: Interdisciplinary Journal in English (ISSN: 2446-3981), No. 7, 2021.

(C) The Journal Editors 
audiences found it "overly chilly and intellectually complex (Lodge). Subsequently, Annibilation was released in limited theatres in the US and direct to Netflix internationally.

However, it is the eeriness, ambiguousness, and complexity of the film, and the fact that it invites more questions than it answers, that makes it so good. After careful analysis, I find that Annibilation is particularly ambiguous in the way it reaches its message. On the one hand, the core message seems to lie in the protagonist Lena's final claim: "It [the Shimmer] was changing our environment. It was making something new." She refuses that this change and mutation is supposed to be an attack on humanity - she sees it as a new and different kind of being. On the other hand, the film, both in terms of visuals and dialogue, leads its audience to reflect on themes such as environmental degradation, disease, and climate change. So, in this article, I will argue that nature is portrayed ambiguously to invite reflection on the topic of environmental degradation and humans' position in nature.

In the following, I provide a brief summary of the film. Additionally, I have chosen to focus on how the mixing of genres adds to the experience of watching the film. Next, I will look at how the theme of mutation, cancer, and self-destruction is portrayed in the film and how it relates to the portrayal of nature and humans' position in nature. I will look at how nature is portrayed as "Apocalyptic Sublime", and how nature in Annibilation relates to William Cronon's ideas of Wilderness. Finally, I will conclude that nature is portrayed ambiguously in a way that both invite reflection on the destruction of our environment and our position in nature, but also instil hope that it is not too late and that change and renewal can still happen.

The film begins with an interrogation of the biologist and former soldier Lena (Natalie Portman) in an isolation cell. As she is interrogated, it cuts to a meteorite silently crashing into a lighthouse. Instead of collapsing, an oily mist ("the Shimmer") expands out from the lighthouse and creates what becomes known as "Area X" - an area of strangely mutated wilderness. After her husband, Kane (Oscar Isaac), returns from a mission to Area X fatally ill, Lena joins the next expedition through the Shimmer along with four other female scientists - a physicist, a geomorphologist, a paramedic (in this case, scientist is perhaps a stretch) and a psychologist. Once they enter through the shimmering dome to the changing ecology of Area X, things start to deteriorate. The team of scientists experiences terrifying attacks from mutated wild animals, footage of the mutated bodies of the former expeditions, and infighting. As the lone survivor, the plot culminates with Lena fighting her doppelgänger in the lighthouse. It is a fight in which she appears victorious, but when she returns to the military base and reunites with the doppelgänger version of Kane, the oily shimmer in their eyes suggests otherwise. 


\section{Genre in Annihilation}

The thing about horror is that it reflects the things we fear, both as individuals and societies. And currently, one of the biggest collective anxieties of humanity are environmental degradation and climate change. In Film Art: An Introduction, Bordwell, Thompson, and Smith write that "the genre [horror] is well suited to suggest the limits to human knowledge" as humans find it horrifying when the laws of the nature we know are violated (338). Many of the elements of horror used in Annibilation is based around the unknown. The film itself somewhat follows the basic order-disorder-order pattern of a horror film (Tudor 34), but in many ways, it deviates from it. It begins and ends with the interrogation of Lena, and the ending of the film is basically revealed during the first ten minutes. It destabilizes the expectations of the audience and causes paranoia.

Ecohorror is a relatively new subgenre to emerge, as the genre plays on these fears and anxieties about the environment (Tidwell "Ecohorror" 115). Christy Tidwell adds in her article "Monstrous Natures Within" that in ecohorror, "human and nonhuman are never truly separate; it is important, therefore, to note ecohorror narratives that challenge this division of human and nonhuman, internal and external." (539). In an ecohorror, the monster is not necessarily a literal monster, it can also be the representation or product of nature; and in Annibilation, there are definitely elements of ecohorror, as it contains literal monsters that are a direct product of ecological mutation. The film plays on the duality of human and nonhuman, and the merging is terrifying as it reminds us of the fact that humans are not outside nature, and that there is a limit to human knowledge and what we think is possible.

In addition to ecohorror, Annibilation deploys elements of body horror, a subgenre often found mixed into ecohorror (Tidwell "Ecohorror" 116). The subgenre is characterized "by the manipulation and warping of the normal state of bodily form and function" which is terrifying as it "goes against what is considered normal anatomy and function in biological species (not limited to human)" (Cruz 161). It does not play on the fear of death but the fear of lack of autonomy over one's body and its destruction. Annibilation is full of examples of body horror; the many mutations such as the bear with human features and the moving intestines inside the man from the last mission, and subsequent explosion of him. They all play on the paranoias of body horror, and as Andrew Tudor asks in his essay "Unruly Bodies, Unquiet Minds": "If we cannot rely on our bodies then on what can we rely?" If we add nature to this statement, it is the essence of the horror in Annibilation. This is even further emphasized by the fact that the "monster" does not die in the end, as the Shimmer lives on in Kane and Lena's bodies. Consequently, not only the human body but also the rules of nature and the 
environment, cannot be trusted. It invites the audience to reflect on why this mutation is so unnerving and uncomfortable to watch, and what it says about our (human) relationship with nature.

In Annibilation, body horror is not used exclusively to create repulsion and fear. It is also used to point out the imbalance in how we value the human and nonhuman differently. Christy Tidwell applies Mel Y. Chen's theory of animacy hierarchy to ecohorror, a theory that can also be applied to the mix of body horror and ecohorror in Annibilation. Tidwell explains that "some types of life or being are valued more than others (with sentient life at the top of the hierarchy and inanimate objects at the bottom)" ("Ecohorror" 116), and in this hierarchy, humans are placed at the top, animals further down. After Cass Sheppard (Tuva Novotny) has been killed by the bear, she is not entirely dead. The bear has merged with her; it has assumed her voice and words. When the bear attacks the four remaining scientists, the horror is majorly amped up when the sound of Sheppard's screams - "Help me!" echoes from the disfigured bear. It alters the hierarchy of animacy and blurs the lines between human and animal, human and nonhuman, and life and death. Sheppard's fate highlights the "limits of control" (Tidwell "Ecohorror" 117), if not the limits of human knowledge. The lack of solid boundaries between the human and nonhuman is not portrayed as positive but as horrific and bizarre. The mutated bear in Annibilation reflects our fear of the unknown and unexplainable. However, the mutated bear also invites reflection. It looks sickly, with baldness and blood coming from all sorts of places. The agency comes from a place of pain rather than anger, a symbol of the pain we, as humans, directly and indirectly, inflict on nature and other beings.

Lastly, science used in the film makes the story more realistic and, thereby, more terrifying. The theory behind Josie Radek's (Tessa Thompson) explanation of the Shimmer as a prism is real enough. The consistency in the patterns of mutation adds to this sense of realism. Similarly, the theory behind the cell mutation on a microscopic level is also real. The sense of realism is further emphasized by the fact that the official excuse for the evacuation of Area X is a chemical spill, an "ordinary" environmental disaster, which reminds the audience of "real" catastrophes and humans' involvement in climate change. It is thought-provoking that these forces of the film are not entirely fiction, and the horrific potential almost instigates the stress of pre-trauma in relation to climate change and environmental decay.

\section{Mutation, cancer, and self-destruction}

The main part of Lena's narrative begins with a black and white close up shot of a dividing cell. The shot is accompanied by a voiceover of Lena explaining: "This is a cell. Like all cells, it is born from an 
existing cell." This scene is the introduction to one of the main themes of Annibilation: Cell division and mutation.

The plot is riddled with references to cancer and malignant cell division. Inside the Shimmer, rapid cell mutation and bodily alteration echo the cell division from that initial shot. The cell from that shot is a HeLa cell, cancerous cells "donated" in the 1950es and still alive today (Masters 315). The emphasis on these specific cancer cells is supported by the fact that Lena is shown reading Henrietta Lack's biography - the woman who unknowingly provided the cells in the fifties (Masters 316). The theme of cancer is echoed several times through the film, both in Area X where it seems as if the Earth has gotten cancer, and also in the fact that Dr. Ventress (Jennifer Jason Leigh) has cancer. The theme of cancer is closely related to the theme of self-destruction, as cancer is one's body literally attacking itself. This idea of a "sick world" is striking in the context of how nature and the natural environment suffer in the real world, which is a product of human self-destruction. Additionally, it might remind the audience of the fact that we have harmed our environment so much that it actually causes cancer through polluted air or sun exposure.

Another reference to cancer is the shot of lichens on the wall of the old Southern Reach headquarters. The shot frames the wall with the almost fluorescent colored lichens. The non-diegetic underscoring adds to the eerie atmosphere and almost feels like a warning of what is to come. It cuts to a medium shot of Lena as she says: "Malignant. Like tumors." This emphasis on malignant cell division is further highlighted later on when Lena tests her blood. The scene acts as a duplicate of the initial cell division scene, except in this one, the duplicated cell is mutated and fluorescent. The change and mutations are inside the humans now, blurring the lines between human and alien, human and nonhuman. It is as if the only language to describe and portray these anomalies is through allegories and references to disease and death. The most horrifying part of the film is not how the nonhuman world mutates beyond our understanding, but how the human and nonhuman merges in the mutations, and how this "disease" spreads incontrollable to everything inside the Shimmer.

The last example of this cancer theme that I would like to bring attention to, is the spectacle of the tumor-like core of the Shimmer at the end of the film. Dr. Ventress is annihilated in an explosion from the inside, and what was her becomes part of a core that the Shimmer radiates from. In this scene, the bass of the score almost vibrates as the synthesized four-note melody plays, a non-diegetic sound that matches the disturbing, claustrophobic atmosphere of the scene. It emphasizes the theme of destruction but also renewal, as Dr. Ventress becomes something different instead of disappearing. 


\section{The apocalyptic sublime in Annihilation}

Nonhuman nature in Annibilation is portrayed very ambiguously. On the one hand, when the scientists enter through the Shimmer, they enter a world that nature has reclaimed, a world untouched by humans. On the other hand, it is a nature filled with imagery that can be interpreted as a warning against climate change and environmental degradation.

The first reference to environmental decay is when Lena sees the Shimmer from the Southern Reach Base. In a wide shot, the Shimmer pulsates from the forest like a blue-ish flame creating an ethereal barrier between Area X and the rest of the world. As the sunlight breaks through the dark clouds, the frame resembles an oil painting of a forest fire. Niklas Salmose describes this kind of imagery as the "apocalyptic sublime" in scenes that inspire agency to change human behavior (Salmose 1418). He writes:

Through the spectacle of the end of the world, these catastrophe films initiate a particular emotional reaction, which I call the "apocalyptic sublime," as a way of actually representing the effects of climate change. (1417).

Even though the shot of the Shimmer in Annibilation is not a shot with action or change, it still possesses prophetic and contemplative elements as the visual creates an experience of climate change that can incite the audience to reflect on environmental issues in a deeper way. In Annibilation, the visual spectacles of the transformation of Area X stay with the viewer long after the film has ended and the film makes you feel something different than a regular horror or sci-fi film. It does not have any extreme wide shots of active destruction caused by climate change, so it relies mostly on these eerie visual spectacles. The subtlety of these contemplative shots demands that the audience pays attention and ensures that the decoding of these scenes can take days or even weeks after watching.

The scene set right after the scientists have entered this permeable membrane acts almost as a contrast to the shot of the Shimmer. After waking up, what appears to be days after the start of the mission, Lena investigates her surroundings; lush woods illuminated with the prismatic light effect of the sun through the otherworldly, multicolored shimmer. The colors are saturated and warm, and this vibrant coloring creates an atmosphere of exoticness. Adding to the mise-èn-scene is the diegetic sound of birds chirping, but also the non-diegetic high-pitched sound of a waterphone. This creates a feeling of pleasure and anticipation mixed with a little bit of fright and eeriness. It is not the same sense of apocalyptic sublime, but the visual spectacle of the Shimmer is still present even though it is more 
beautiful and perhaps less frightening. The scene acts as a reminder of how a forest "could be" without human interaction. It is a romantic, sublime depiction, but with a layer of the uncanniness of the unknown. It adds to the ambiguousness of the portrayal of nature in Area X, as this scene presents it as beautiful reclaimed wilderness.

\section{Wilderness in Annihilation}

William Cronon writes in "The Trouble with Wilderness: Or, Getting Back to the Wrong Nature" that for many people, "wilderness stands as the last remaining place where civilization, that all too human disease, has not fully infected the earth." (7). The phrasing can seem a bit ironic in the context of Annibilation. As written earlier, the references to disease and cancer in the film are many, and the wilderness that has reclaimed Area X is presented as a direct product of this "disease." However, if one takes a closer look at the portrayal of nature in Annibilation, it holds more than just references to disease and disaster, because in Annibilation we return to wilderness, a wilderness that is not "(just) out there" but "(also) in here" (Cronon 20), closer to humans, and sometimes literally merged with humans.

The wilderness, and nature in general, in Annibilation is complex and is a place of both rebalance and sheer horror. If we return to the theme of echoes, one of the examples of this complexity is the house where the bear with Sheppard's voice attacks the remaining scientists. It is an exact duplicate of the house that Lena and Kane lived in as a married couple, a house the audience sees in a montage very early on in the film. This second house inside Area X has been taken over by the Shimmer, covered in ivy, and in a state of decomposition. Andrew Hageman writes about this house:

Rather than emphasising spookiness contained within the house as seen from outside (as in Hitchcock's Psycho [1960]) or the interior as a bulwark against spookiness without the house (as in Romero's Night of the Living Dead [1968]), this montage establishes the house/home as in itself permeable and permeated. Put another way, the architectural artefact typically associated with dividing inside from outside, private from public, and so on, is implied to be much more porous than all that. (259).

The stability of the home has been overthrown by nature, and it is a space where wilderness has begun to rebalance itself. All boundaries inside Area X are crumbling, both in terms of physical boundaries (bodily and architectural) and more intangible boundaries. Nature is really "in here". As a setting, the 
house is dark and claustrophobic, and the fact that the audience and the characters are unable to see what is going on in the scene with the bear adds to the horror. The same is the case with the military base, a place where humans used to dominate, which has been taken over by wilderness. The base is the setting of the first bear attack (where Sheppard dies) and has the effect that nonhuman nature seems to "fight back" both in terms of natural decay and the overgrowth of lichens and ivy, and in terms of actual physical attack on the humans.

But not all mutation is portrayed as an attack by this alien power. As the scientists approach the duplicate house, they discover trees that have taken a human form. As a wide shot in a shot-reverseshot sequence, we see the plant humans, both adults and children, in the foreground of a field, complete with flowers and leaves and the Shimmer glistening behind. In this scenery, human and nonhuman DNA have merged. In the reverse shot, we see Thorensen's (Gina Rodriquez) horror at the sight, but also Lena and Josie Radek's curiosity. They can make sense of the experience and to them, it is strange if not beautiful, whereas Thorensen finds it inexplicable.

Especially Josie Radek is fascinated by this particular mutation, and she discovers it within herself the next day. In a wide shot, we see her sitting on a branch in front of the house, wearing only a white tank top. This is significant as it was revealed earlier in the film that she used to self-harm, and it indicates that she has found peace within herself. It cuts to a medium shot of Josie and Lena, where Josie tells Lena, almost serenely, that "it will be in all of us." By "it," she means the Shimmer, but she does not seem to mind this DNA mixing. Moments later, she gets up and says: "Ventress wants to face it. You want to fight it. But I don't think I want either of those things." What she wants is to merge with nature peacefully, and so she lets the Shimmer in and walks out of shot while transforming into a human-shaped plant. It is both eerie but also somewhat beautiful. She does not die, she just changes and becomes something else. Something that is not painful or horrific, but instead natural and calm, and it enforces Cronon's point that "wilderness teaches us to ask whether the Other must always bend to our will" (18).

Thus, nature and wilderness are not portrayed as an illusionary version where "the human is entirely outside the natural" (Cronon 17). Instead, it is a part of the humans, both their spaces of living and their bodies. It seems to be closer related to Cronon's main point; that nature and wilderness are everywhere, and that humans should learn to live with and respect the otherness of nature (Cronon 18-19). This part of Annibilation challenges the conception of nature and humanity being separate and illustrates how humans could try to live more as one with nature. 


\section{Conclusion}

As a form of eco-media, Annibilation has a great potential to incite reflection on environmental issues and humans' position in nature; reflection that might lead to agency and change in its audience. Even though it is not about manmade environmental destruction, the portrayal of the effects of the Shimmer has many parallels to manmade pollution and environmental destruction. Moreover, the film offers a new perspective on the relationship between human and nonhuman.

The continuous merging of human and nonhuman reminds the audience of the fact that humans are not outside nature. The elements of ecohorror reflect the fear of climate change and environmental decay, and the changing ecology in Area X is a symbol of how we fear the lack of control that follows. This is enforced by elements of body horror, which is used both to create moments of undiluted horror in the film, but also to get the audience to think about their relationship with nature when faced with these human/nonhuman mutations. The science adds realism to the film, and especially in the current climate, mutations and disease seem like an absolute nightmare. Nature is portrayed as dark and the horror elements cause much of this darkness. Additionally, the horror elements invite the audience to reflect on the fact that humans' position in nature is uncertain, that there is a limit to human knowledge, but also that some of the things we do know are absolutely terrifying.

The theme of cancer and self-destruction implicitly reminds the audience about all of the ways we are currently destroying our environment and how this destruction literally contributes to our destruction - our annihilation. In addition to the theme of destruction, is the theme of renewal, which somehow creates hope that we can live in harmony with nature at some point - that humans can change. Because, as William Cronon writes, if humans are entirely outside nature and cause this harm, the only possible solution is to collectively commit suicide (Cronon 13), and this solution is not exactly the most productive. So, the theme of renewal and sense of hope adds to the ambiguity of the message, but also makes the portrayal of nature and humans' position in nature more optimistic.

Nature in Annibilation is portrayed differently than any other dystopian film about environmental disaster. It makes you feel something different, and one of the elements that cause this feeling is the use of the apocalyptic sublime. These visuals create an experience of climate change that encourage reflection in the audience and stay with them long after the film has ended. This reaction can come from shots of destruction and anomalies, but also shots of the pristine and dreamy. It incites both fear and hope.

The final message of the film is not always completely clear, as many of the elements contrast each other. For example, nature is portrayed as both horrific and beautiful, as are the mutations. This 
complexity mirrors the complexity of the real world, and I would argue that the ambiguities of the portrayal of nature, and the position of humans in nature, ask the audience what it means to be human and how we want to live. 


\section{Works cited}

Bordwell, David, et al. Film Art: An Introduction. McGraw-Hill Education, 2017.

Cronon, William. "The Trouble with Wilderness: Or, Getting Back to the Wrong Nature."

Environmental History, vol. 1, no. 1, 1996, pp. 7-28. doi:10.2307/3985059.

Crosby, S. L., Hageman, A., Mancus, S. D., Platt, D., and Sperling, A. (2019) Annibilation: A

Roundtable Review. Gothic Nature. 1, 256-281. Accessed on January 5,

https://gothicnaturejournal.com/wp-content/uploads/2019/09/Annihilation_256-281.pdf.

Cruz, Ronald Allan Lopez. "Mutations and Metamorphoses: Body Horror Is Biological Horror."

Journal of Popular Film and Television, vol. 40, no. 4, 2012, pp. 160-168.

doi:10.1080/01956051.2012.654521.

Garland, Alex, director. Annibilation. Netflix, 2018, www.netflix.com/title/80206300.

Hageman, Andrew. "Why You Should Lichen Alex Garland's Annibilation." Part of Annibilation: A

Roundtable Review. Gotbic Nature. 1, 256-281. Accessed on January 5,

https://gothicnaturejournal.com/wp-content/uploads/2019/09/Annihilation_256-281.pdf.

Lodge, Guy. "Was Annihilation Too Brainy for the Box Office?" The Guardian, Guardian News and

Media, 10 Mar. 2018, www.theguardian.com/film/2018/mar/10/annihilation-netflix-release-alex-

garland-ex-machina.

Mancus, Shannon Davies. "Prison/Prism: Refraction as Radical Praxis in Annibilation." Part of

Annibilation: A Roundtable Review. Gothic Nature. 1, 256-281. Accessed on January 5,

https://gothicnaturejournal.com/wpcontent/uploads/2019/09/Annihilation_256-281.pdf.

Masters, John R. "HeLa Cells 50 Years on: the Good, the Bad and the Ugly." Nature Reviews Cancer, vol. 2, no. 4, 2002, pp. 315-319. doi:10.1038/nrc775.

Salmose, Niklas. "The Apocalyptic Sublime: Anthropocene Representation and Environmental Agency in Hollywood Action-Adventure Cli-Fi Films." The Journal of Popular Culture, vol. 51, no. 6, 2018, pp. 1415-1433. doi:10.1111/jpcu.12742.

Thompson, Anne. “'Annihilation' Director Alex Garland Speaks Out on Screwing With Genre and

Studio Panic Attacks." IndieWire, 8 Apr. 2018, www.indiewire.com/2018/04/annihilation-

director-alex-garland-devs-television-1201950154/.

Tidwell, Christy. "Ecohorror." Posthuman Glossary, by Rosi Braidotti and Maria Hlavajova,

Bloomsbury Academic, an Imprint of Bloomsbury Publishing Plc, 2018, pp. 115-117. 
Tidwell, Christy. "Monstrous Natures Within: Posthuman and New Materialist Ecohorror in Mira Grant's Parasite." Interdisciplinary Studies in Literature and Environment, vol. 21, no. 3, 2014, pp. 538549. doi:10.1093/isle/isu081.

Tudor, Andrew. “Unruly Bodies, Unquiet Minds.” Body \& Society, vol. 1, no. 1, 1995, pp. 25-41. doi:10.1177/1357034x95001001003. 